\title{
Bioactive molecules from plants: a prospective approach to combat SARS-CoV-2
}

\author{
Gagan Kumar Panigrahi ${ }^{1}$. Shraban Kumar Sahoo ${ }^{1}$ Annapurna Sahoo ${ }^{1}$. Shibasish Behera ${ }^{1}$. Snigdharani Sahu ${ }^{1}$. \\ Archana Dash $^{1} \cdot$ Kunja Bihari Satapathy ${ }^{1}$
}

Received: 18 May 2021 / Accepted: 8 July 2021

(C) Institute of Korean Medicine, Kyung Hee University 2021

\begin{abstract}
The emergence of Severe Acute Respiratory Syndrome Coronavirus 2 (SARS-CoV-2) or 2019 Novel Coronavirus (2019$\mathrm{nCoV}$ ) has put the entire globe into unrest, primarily due to unavailability of specific drug against the viral proteins. In the last two decades the world has withstood many contagious disease crashes. SARS-CoV-2 has put the world and the mankind in danger. It is spreading unstoppably all over the world. The virus is evolving and thus the pathogenicity of SARS-CoV-2 strains has been different and making it difficult to develop a broad-spectrum anti-viral molecule that would be effective against all the SARS-CoV-2 variants. This imperative situation demands development of molecules for effective treatment against SARS-CoV-2. The phytomolecules or the bioactive molecules of plants could be a great alternative to combat SARSCoV-2. The bioactive molecules with their antiviral properties and the secondary metabolites may effectively deactivate the functioning of viral proteins. The structural configuration of 2019-nCoV proteins and genomic information are available, thus contributing immensely for fast molecular docking studies and hence, enables screening of numerous accessible phytomolecules. In the current study, we have essentially highlighted common phytomolecules against the known viral proteins and described the mode of action of few plant-derived molecules which have the potential to suppress the activity of the viral proteins.
\end{abstract}

\section{Graphic abstract}

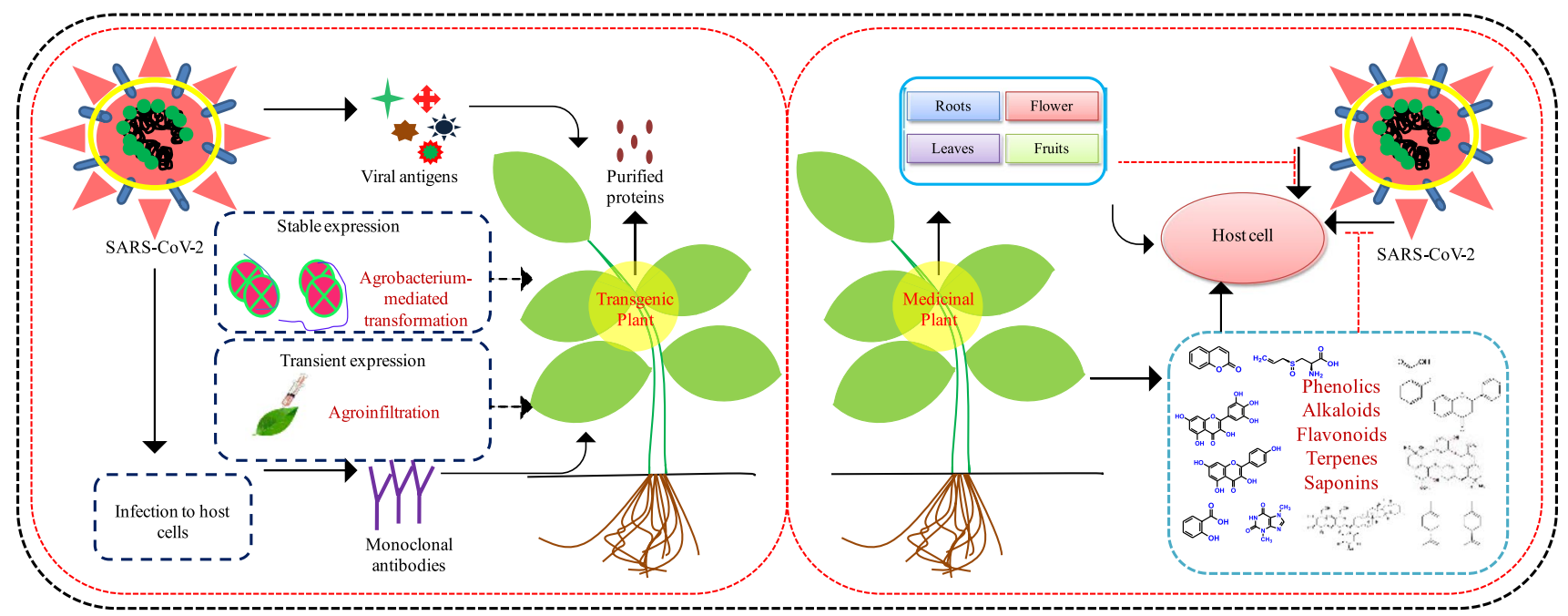

Keywords SARS-CoV-2 $\cdot$ Pathogenicity $\cdot$ Antiviral $\cdot$ Phytomolecules $\cdot$ Secondary metabolites $\cdot$ Molecular docking

Gagan Kumar Panigrahi, Shraban Kumar Sahoo, and Annapurna

Sahoo have contributed equally.

Extended author information available on the last page of the article 


\section{Introduction}

The outburst situation caused due to the Severe Acute Respiratory Syndrome Coronavirus 2 (SARS-CoV-2) represents a serious public health crisis across the globe. Since, December 2019, the whole world is suffering from the crisis of Corona virus. The virus is supposed to be originated from bats and latter on transmitted to humans. The outbreak of this human pathogen emerged in the city of Wuhan in China, and resulted to human disease, termed as COVID19 (Arti and Bhatnagar 2020; Burki 2020; Chen et al. 2020; Huang et al. 2020). World Health Organization (WHO) declared Public Health Emergency of International Concern (PHEIC) owing to its fast rate of transmission within the humans (Chan et al. 2020; Chen et al. 2020; Li et al. 2020a, b; Sun et al. 2020). Over 14.57 million cases have been detected in 213 countries till now. The virus possesses crown like spikes on its outermost layer, so it was named as coronavirus (Fig. 1). The SARS-CoV-2 belongs to the beta $(\beta)$, Coronavirus genus, closely related to the previously identified severe acute respiratory syndrome Coronavirus (SARS-CoV), family Coronaviridae, order Nidovirales and the sub family Orthocoronaviridae (Lu et al. 2020; Shereen et al. 2020; Wu et al. 2020; Zhou et al. 2020). Middle East Respiratory Syndrome (MERS) and severe acute respiratory syndrome (SARS) are commonly caused by viruses belonging to the Coronaviridae. Coronaviridae has two sub families; Torovirinae and Coronavirinae and the members of Coronaviridae family affects the mammals and aves (Zhou et al. 2020). The virus is $65-125 \mathrm{~nm}$ in diameter and the genomic content is estimated to be 26-32 kilobases. SARS$\mathrm{CoV}-2$ is an RNA virus and it contains single-stranded RNA genome. The virus has four subgroups i.e. Alpha $(\alpha)$, Beta $(\beta)$, Gamma $(\gamma)$ and Delta $(\delta)$. The Alpha $(\alpha)$ and Beta $(\beta)$ corona virus infect mammals. The Beta $(\beta)$ corona virus causes respiratory illnesses to humans and the Gamma $(\gamma)$ and Delta $(\delta)$ corona virus affect aves and some selective mammals (Woo et al. 2012). SARS-CoV-2 makes use of

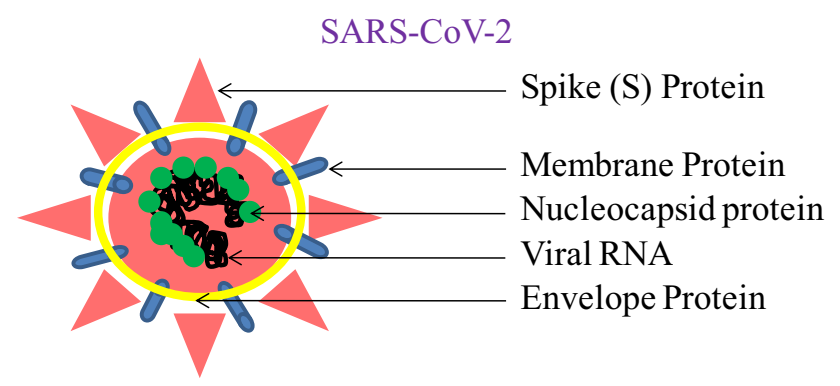

Fig. 1 A typical schematic view of SARS-CoV-2. The RNA virus possesses 4 structural proteins known to be spike protein, membrane protein, nucleocapsid protein and envelope protein its own proteins to safely harbour in the host cells (Fig. 1). Reportedly, a densely glycosylated spike (S) protein, SARS$\mathrm{CoV}-2$ main protease $\left(\mathrm{M}^{\mathrm{pro}}\right)$ and RNA-dependent RNA polymerase ( $R d R p)$ are defining features paving the path of virus from entry to infection in the host cell (Cui et al. 2019; Lung et al. 2020; Ton et al. 2020; Wrapp et al. 2020). Essentially, the $\mathrm{S}$ protein undergoes extensive structural reorganization in order to fuse with the host membranes, thus establishing a physical link between the virus and the host cell (Booth et al. 2003; Li et al. 2020a). Eventually, a stable conformation is established (Wrapp et al. 2020). RdRp catalyzes the replication event, resulting in the synthesis of viral RNA. Remarkably, SARS-CoV and SARS-CoV-2 share similar nucleotide sequences and resulting RNA-dependent RNA polymerase (Liu et al. 2020). The SARS-CoV-2 proteins, metabolites and host cell factors can be targeted to reduce the viral replications within the host cells as for instance; the viral protein $\mathrm{M}^{\text {pro }}$ facilitates the synthesis of functional viral proteins out of the precursors (Fig. 2). $\mathrm{M}^{\text {pro }}, \mathrm{S}$ and RdRp proteins can be targeted for developing diagnostics, antibodies and vaccines. Human corona virus ( $\mathrm{HCoV}$ ), $\mathrm{HCoV}$ OC43, MERS-CoV and SARS-CoV are some of the viruses which causes respiratory problems in human and are being transmitted from one individual to another. This viral infection is transmitted from human to human through the coughed, sneezed droplets or by the contact of infected surface. The solved three dimensional structures of the viral proteins provide an outstanding ground for discovering specific ligands (Liu et al. 2020). In South-east countries like South Korea, China, Japan and India, many traditional medications are used to treat SARS-CoV-2, but the efficiency of the compounds are limiting and molecular mechanisms are also unclear. Plants possess amazing defense competence towards diseases (Panigrahi and Satapathy 2021; Panigrahi et al. 2021). The phytomolecules are also known as the bioactive compounds which have the tendency to modify the cellular physiological processes. Here, we highlight several phytomolecules having the ability to restrict the activity of SARS-CoV-2 and thus future studies may reveal the underlying molecular mechanism(s) and the efficacy of these phytomolecules.

\section{Covid-19 and its transmission}

People are worstly affected by Covid-19 in different ways. The most common symptoms of Covid-19 include fever, dry cough, and tiredness. It also shows symptoms like diarrhoea, headache, loss of taste or smell, aches and pain, rash on skin, discoloration of finger on toes etc. The symptoms of Covid-19 are same as the symptoms of corona virus $(\mathrm{CoV})$ which had appeared in 2003 as SARS. It was named as SARS-CoV-2 by WHO on 11th February 2020 and the disease was termed as CoV disease-19 (Covid-19) (Jiang 
Fig. 2 Possible potential targets to restrict the activity of SARSCoV-2. There are number of promising targets which can be exploited to inhibit the viral infection. Metabolites including nucleoside analogues and antimetabolites can be targeted to prevent viral replication. Likewise, host cell proteins such as ACE-2 (Angiotensin Converting Enzyme-2), Importin $\alpha 1-\beta 1$ inhibitors and Signal transducers and activators of transcription 1 (STAT1) can also be targeted. Three categories of proteins; structural, non-structural and accessory can also be targeted to repress the activity of the virus

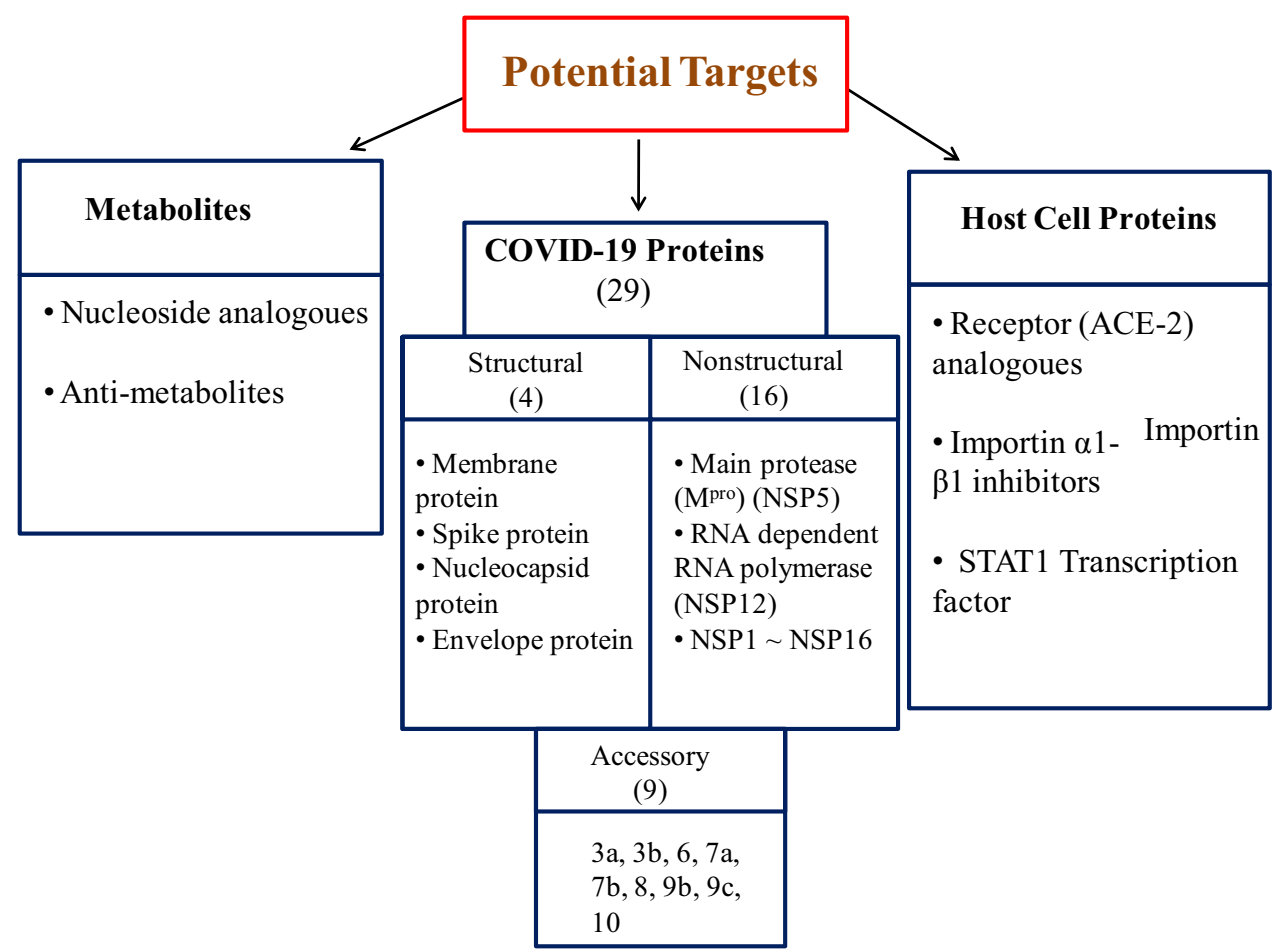

et al. 2020; Velvan and Meyer 2020; Wang et al. 2020a,b,c). Transmission of SARS-CoV-2 is severe as compared to the SARS-CoV. Severe lung damage pneumonia like symptoms were seen in patient suffering from SARS-CoV-2 (Zhu et al. 2020). The Chinese center for disease control and prevention sent a medical emergency team to assist the health authorities of Hubai province and Wuhan city to inspect about the disease, but later WHO gave confirmation about the outbreak of the disease. According to WHO the disease was not caused by any particular animal in Hunan South China sea food market place. Subsequently the transmission of the disease occurred rapidly, the situation became out of control when the whole world was affected badly. The genomic evidences related to SARS-CoV-2 were published (Ferh et al. 2017; Zheng 2020). All possible ways including vaccines, monoclonal antibodies, oligo nucleotides, interferons and small molecules, drugs were tried to be developed for the control of SARS-CoV-2. WHO recommended to practise social distancing among people so as to deaccelerate the higher rate of infections.

In countries including China, United States of America, Italy, India and many other countries, SARS CoV-2 had spread rapidly (Giovanetti et al. 2020; Paraskevis et al. 2020). Several studies suggested that bat may be the cause of SARS- CoV-19, but it is not confirmed that bat is the stockpile of SARS-CoV-2. CoVs acts as nonfatal pathogen, which cause only common cold in case of humans (Li et al. 2005a,b; Hampton 2005; Banerjee et al. 2019; Giovanetti et al. 2020; Paraskevis et al 2020; Paules et al. 2020).
Covid-19 mainly spreads and enters into human body in 3 different ways; firstly by droplets transmission-by sneezing, coughing; secondly by the patient it transmits through contact-by touching mouth, nose and eyes in contaminated area; thirdly, by aerosol transmission (Guan et al. 2020; Jin et al. 2020). In case of humans, symptoms such as abdominal discomfort and diarrhoea are also prominent. It was found that the Angiotensin-Converting Enzyme 2 gene (ACE2) was highly expressed in Covid-19 patients (Zhang et al. 2020a, b). The most general symptoms of this disease are cold, fever, myalgia or fatigue, common pneumonia and complicated dyspnoea and less common symptoms are headache, diarrhoea, hemoptysis, runny nose and phlegm producing cough. The affected individuals showing mild symptoms usually get recovered within one week whereas individuals showing acute symptoms are prone to damage in alveolar tissues and subsequently leading towards severe respiratory failure. Mainly the old aged patients already suffering from diseases such as cirrhosis, tumour, hypertension, diabetes and coronary heart damage get very severe problems and proven to be highly fatal (Arti et al. 2020; Huang et al. 2020; $\mathrm{Li}$ and Clercq 2020; Li et al. 2020a, b). As compared to other countries, the proportion of infection in India was low i.e. 1.9\%. In India lockdown started from 25th March 2020, all over the country, after the rapid transmission of Covid-19 and situation was back to normal around the start of 2021. But, unusually India is witnessing the dreadful nature of this pandemic now, where it is believed to be because of a variant strain of SARS-CoV-2. Currently, nation-wide crisis 
has again led to lockdown situations and speculations suggest that the rise in Covid infections would reach around the mid of May, 2021.

\section{Conceivable drugs and vaccines against Covid-19}

On December 2019, an unknown outburst of viral Pneumonia in Wuhan city made clinicians across the globe to analyze different therapeutics to defy Covid-19. Since definite vaccine for Covid-19 was not discovered, the disease got escalated all over the world and forced the clinicians to use former convenient drugs for the treatment. Covid-19 treatment may involve targeting of Autophagy and endocytic signaling events (Yang et al. 2020). Primarily, virus and host cell interaction is critical and there are several check-points were suitable drugs may be targeted (Figs. 3 and 4). Essentially, SARS-CoV-2 mainly affected the lungs and majority of fatality was due to the collapse of respiratory system. Consequently, patients were first aided with oxygen therapy, extra corporeal membrane oxygenation (ECMO) and invasive mechanical ventilation. Many drugs such as remdesivir, ribavirin, nitazoxanide, penciclovir, chloroquine, nafamostat and favipiravir were tested in counter to this lethal disease on Vero E6 cells and was monitored that chloroquine and remdesivir were the most suitable drugs with less cytotoxic effects (Wang et al. 2020a, b, c). In addition to these drugs, antibiotics such as hydroxychloroquine and azithromycin were able to control the viral growth. Lopinavir, baricitinb, interferon- $\alpha$ and ribavirin may be given to the patients with acute respiratory system, but addition of lopinavir has side effects like diarrhoea, nausea or liver damage (Hirsch et al. 2013). Use of steroids can check the inflammatory damage, but a heavy dose has several harmful effects (Booth et al. 2003; Griffith et al. 2005; Minneci et al. 2009; Clark and Baillie 2020). Plasma therapy was also under observation for the treatment of Covid-19. This therapy essentially involved in deriving antibodies from B-lymphocytes of the recovered patients. It can help in reducing inflammation and viral growth. Traditional Chinese Medicine (TCM) therapy was another choice for the treatment of Covid-19 as it was a successful therapy curing disease from ancient time. It was highlighted that Lian Hua Qing Wen and Shu Feng Jie Du capsules gave positive response in treatment of SARS-CoV-2 (Lu 2020). The western medicines and combination of western and traditional Chinese medicines were experimented separately for the effectiveness towards the disease and was found that the combination of western and traditional Chinese medicine was more effective. The combined medicine stabilized the body temperature in less time and also lowered the mortality rate. Vaccination was necessary to cease the transmission and develop immunity against Covid-19. Recombinant protein subunits for MERS, DNA plasmids, viral vectors, virus like particles and nanoparticles were used to develop the first vaccine. The mRNA vaccine was first tested in humans on March 16, 2020 in United States of America. The vaccine mimics mRNA 1273 which encodes spike protein of SARS-CoV-2 and is primarily enclosed within nanomaterials. However, the understanding of the SARS-CoV-2-host interaction(s) and the underlying molecular mechanism(s) still remains blurred.

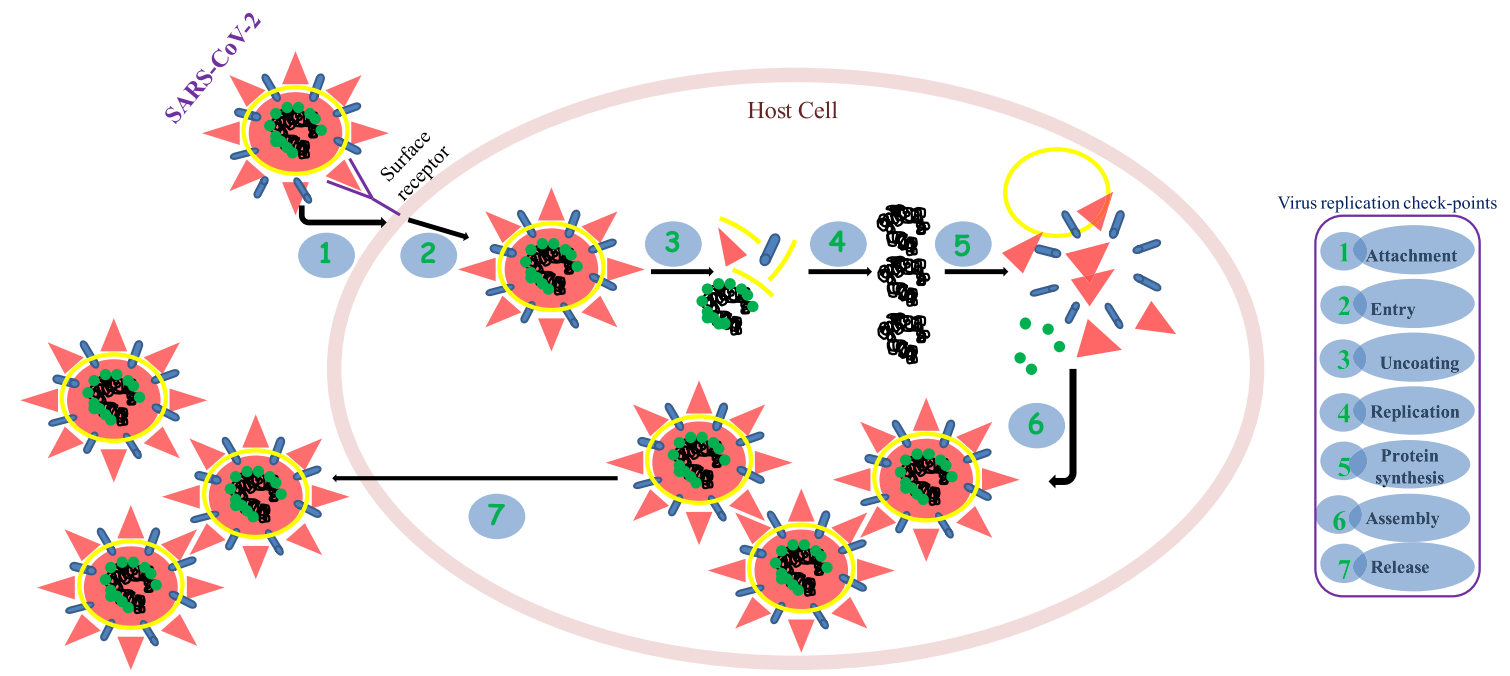

Fig. 3 Possible virus replication check-points to restrict the activity of SARS-CoV-2. Virus interacts with host cell by associating with specific cell surface receptors and thereby establishes stable interaction followed by various downstream events allowing the virus to proliferate and infect the host system 


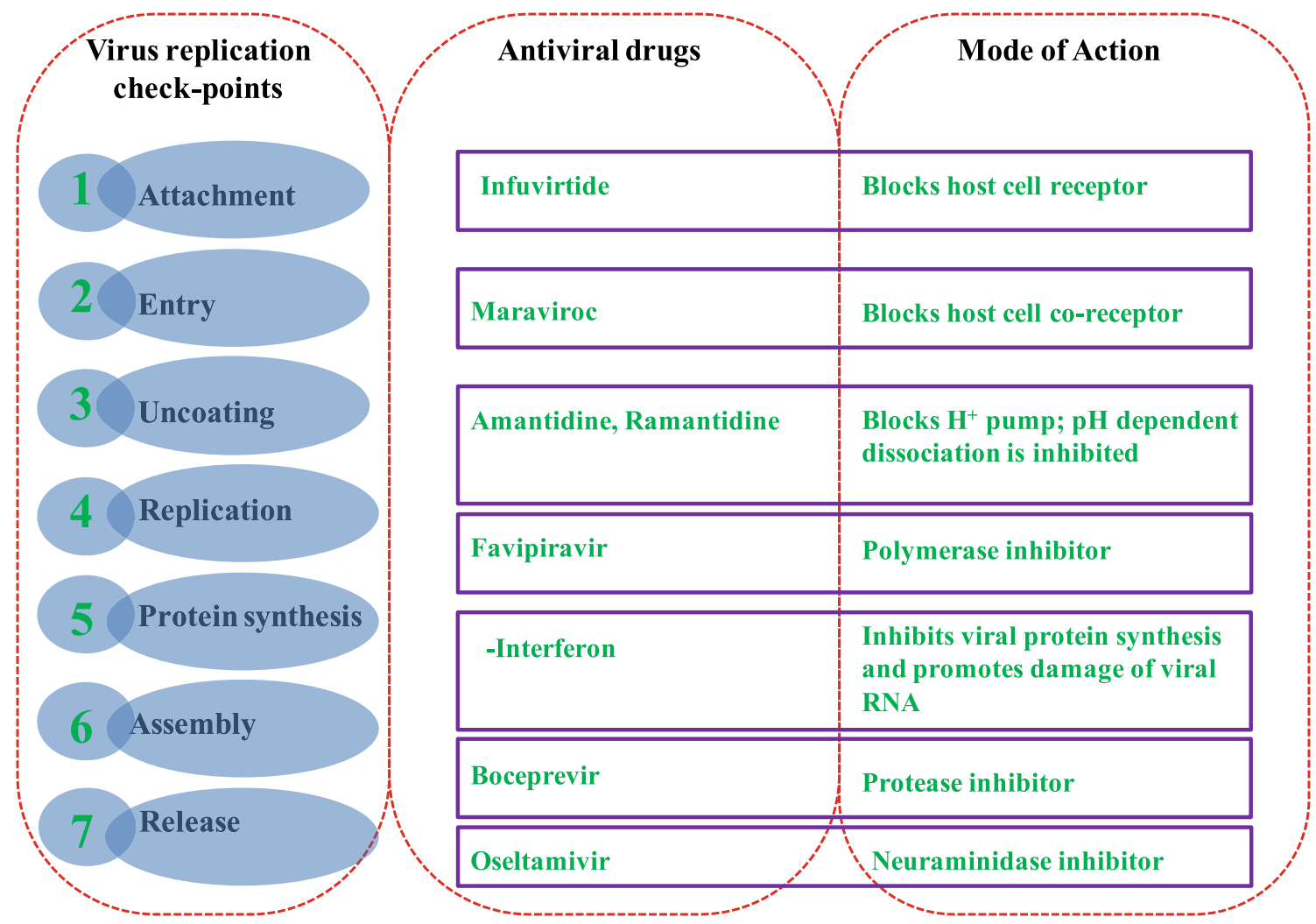

Fig. 4 Few antiviral drugs having the potential to restrict virus replication in the host cells. Various synthetic antiviral drugs have proven activity of inhibiting viral propagation by strategically interfering in several check points related to host-virus interaction

\section{Bioactive molecules against coronavirus}

\section{Plant metabolites}

The primary and secondary metabolites have different group of compounds (Fig. 5). Improvised analytical techniques would modulate in generating informations regarding bioactive molecules derived from various natural sources including plants. Thus, sophisticated analytical techniques and choosing right natural source may help in overcoming many diseases, particularly for those having no specific treatment. The major compounds that are categorized as primary metabolites and found in all the living systems include proteins, lipids, carbohydrates, nucleic acid and chlorophyll (Fig. 5). Likewise, secondary metabolites include flavonoids, phenol acid, alkaloids, volatile oils, terpenes, saponins, tannins, and many more (Dias et al. 2012; Azmir et al. 2013; Woolley 2001; Panda et al. 2020). Different species of plants accumulate specific secondary metabolites and also plays an imperative role during survival and adaptability process of the plant primarily by modulating the cellular homeostasis (Panigrahi and Satapathy 2020a, b, c; Sahoo and Satapathy 2020).

\section{Bioactive molecules}

The modern science is exploring new natural derivatives present in variety of living organisms and subsequently these natural products display highly efficient therapeutic properties for treating various diseases (Dash et al. 2020). These natural products have diverse application and unique properties which are useful for medicine production processes (Kang et al. 2013). From ancient time, the traditional natural medicines are playing vital role in disease control and ancient medicine practitioners were expert in this field with or without knowledge of bioactive molecules. Now-adays researchers are focusing more on plant-baed bioactive molecules to overcome dreadful disease as these products have negligible side effects on humans (Kang et al. 2013). The therapeutic capacity of medicinal plants is due to their chemical composition which primarily comprises of vitamins, minerals and bioactive molecules (Singh et al. 2020a). Many scientific studies suggest that the synthetic vitamins and minerals cannot give the benefits as much as natural products. The medicinal plants contain many minerals and vitamins that easily get assimilated by human body. Natural products contain more bioactive molecules as it has complementary action between vitamins, enzymes and 
Fig. 5 A variety of plant metabolites involved in regulating plant physiology. The primary and secondary metabolites have different group of compounds. The major compounds that are categorized as primary metabolites and found in all the living systems include proteins, lipids, carbohydrates, nucleic acid and chlorophyll. Likewise, secondary metabolites include flavonoids, phenol acid, alkaloids, volatile oils, terpenes, saponins, tannins, and many more

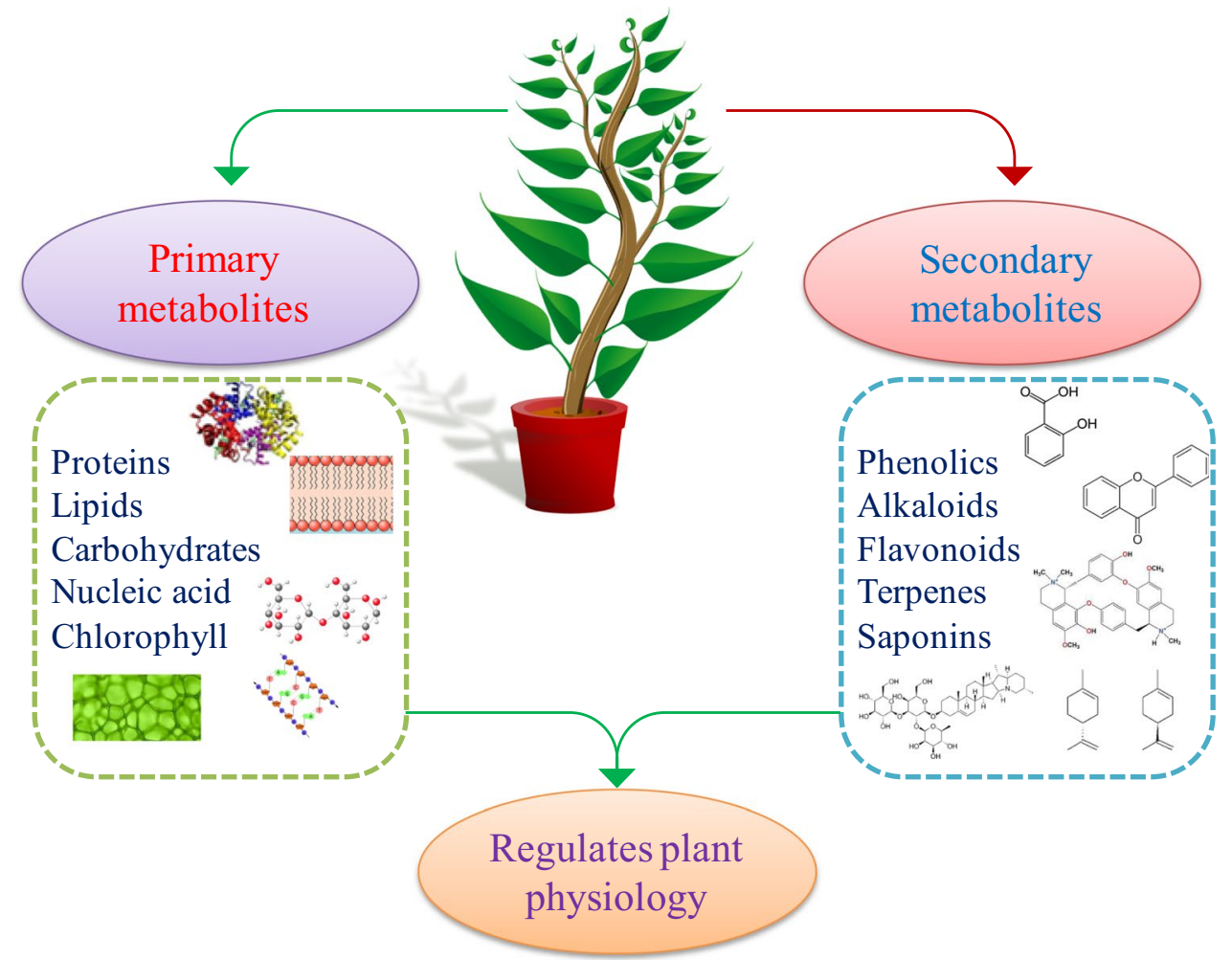

minerals (Singh et al. 2020b). Synthetic drugs posses more side effects and have more disadvantages towards human body as compared to natural medicines (Singh et al. 2020b). The plant products have phytomolecules containing active ingredients with therapeutic properties (Dias et al. 2012). The secondary metabolites are specific from species to species. Bioactive molecules harbour therapeutic, toxicological and immune stimulation properties and could prove to be an effective alternative against viral diseases (Panigrahi and Satapathy 2020d; Sahoo and Satapathy 2020).

Across the globe, the mankind is facing the deadly effect of Covid-19. Every vaccine is under the trial basis and it has been reported that the drugs that were generally used for the Human Immunodeficiency Virus (HIV) such as lopinavir/ritovir can be used for treating Covid-19 patients (Wang et al. 2020a, b, c). Some other drugs like pitavastatin, nelfinavir, perampanel and praziquantel can also be used against covid-19 (Xu et al. 2020). Plants are repositories of several types of natural bioactive molecules which might play a critical role in addressing the current pandemic. Essentially the various secondary metabolites which are secreted by the plant cells can be utilized for developing anti-viral drugs using plant biotechnological approaches (Fig. 6). Usually secondary metabolites such as flavonoids, alkanoids, terpenoids and polyphenols possess antiviral properties (Yang et al. 2018; Khaerunnisa et al. 2020; Singh et al. 2020c). Medicinal plants are abundantly rich in phenolic metabolites (Yang et al. 2018). Molecular docking studies revealed that medicinal plants-derived phytomolecules such as quercetin, curcumin, kaempferol, catechin, naringenin, buteolin7-glucoside, apigenin-7-glucoside, demethox-yeurcumin, obeouropein and epigallao-catechin that have the potential for combating against SARS-CoV-2 (Singh et al. 2020c). These bioactive molecules display similar pharmacophore properties as nelfinavir as revealed in in silico analysis. The bioactive phytomolecules released from a range of plant species bears therapeutic properties against SARS-CoV-2. Many phytomolecules such as rutin, diacetyl curcumin, diosmin, (E)-1-(2-Hydroxy-4-methoxyhenyl)-3 [3-[(E)3-(2-hydroxy-4-methoxyphenyl)-3-oxoprop-1enyl]phenyl] prop-2-en-1-one, beta'-(4-Methoxy-1,3-phenylene)bis(2'hydroxy-4',6'dimethoxyacrylophenone) and apiin are also effective anti-virals (Adem et al. 2020; Singh et al. 2020c; Table 1). Lupane-type triterpenes, R-cadinol, labdane-type and abietane-type diterpenes, lignoids, curcumin and sesquiterpenes are few other identified bioactive compounds which would also play an vital role in defending the host cells against SARS-CoV-2 (Wen et al. 2007; Yang et al. 2020; Gong et al. 2008; Nguyen et al. 2012). In the last decade, many numbers of traditional Chinese herbs have been identified which were effective against SARS-CoV (Chang et al. 2012). Herbal extracts from Houttuynia cordata, Chinese Rhubarb extracts and beta-sistosterol from roots of Isatis indigotia that have the potential to impede the enzymatic activity of SARS-CoV (Chang et al. 2012; Singh et al. 2020c). Many more phytomolecules like epigallocatechin 


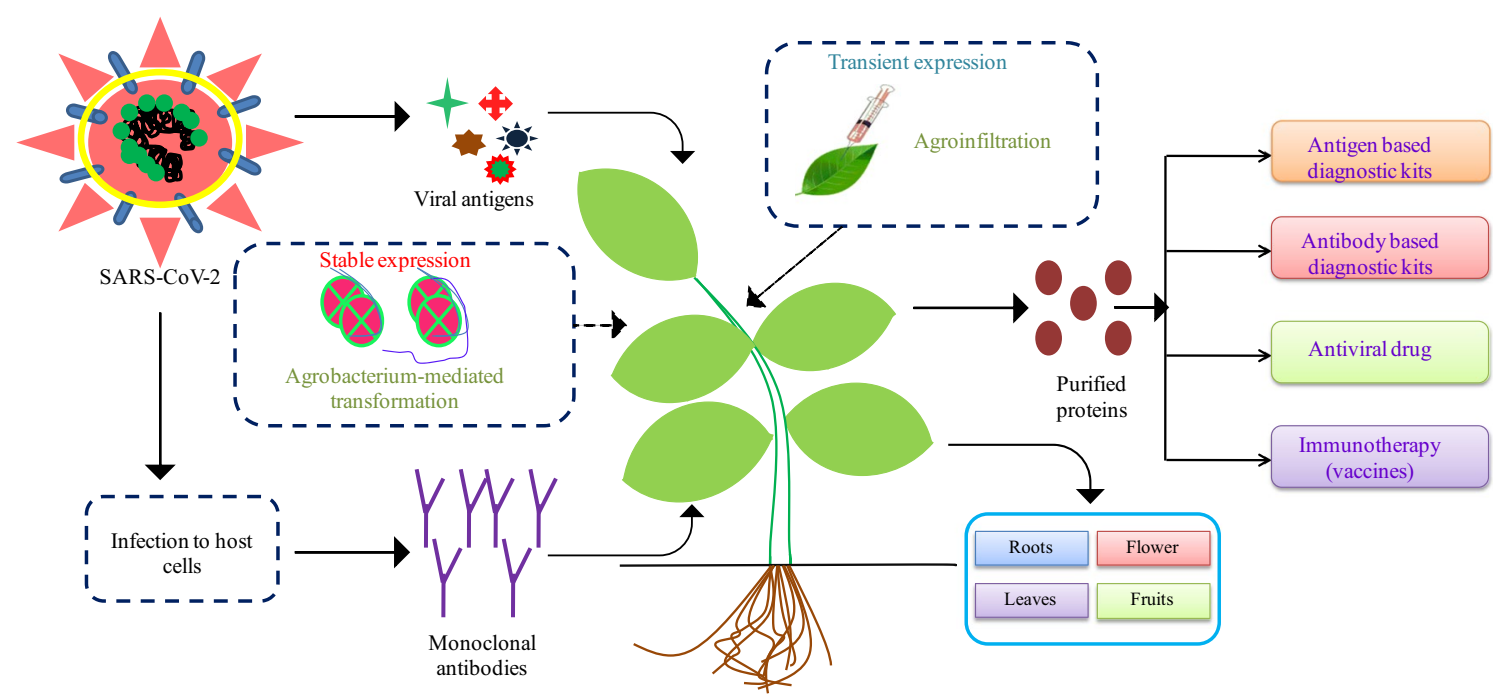

Fig. 6 Developmental routes for plant-based diagnostics and therapeutics against SARS-CoV-2. Plant-based secondary metabolites can be substantially utilized for developing anti-viral drugs using plant biotechnological approaches

gallate, aloe-emdin, quercetin, rhoifolin, hesperetin, sinigrin, $3 \beta$-Friedelanol from Euphorbia neriifolia, blancoxanthone from the roots of plant species such as Calophyllum blancoi, Lycoris radiata, Pyrrosia lingua, Artemisia annua and Lindera aggregata possess anti-viral activity against SARCoV-2 (Shen et al. 2005; Singh et al. 2020c). Molecular docking simulations have revealed that the phytomolecules from Nilavembu kudineer have the potential to bind to the host cell viral receptors; ACE2 and thus may mediate the restriction of virus to attach to the host cells ( $\mathrm{Li}$ et al. 2005a,b; Singh et al. 2020c; Walter et al. 2020).

\section{Mode of action of phytochemicals against viral pathogens}

Viral diseases are causing a distressing threat for human beings across the globe. A number of viral diseases are continuously reported which predominantly display severe health related issues and unfortunately unavailability of effective antiviral cure makes these diseases more severe (Kapoor et al. 2017). Essentially, flaviviruses and alphaviruses are the causative agents for several types of viral diseases such as chikungunya, influenza and HIV which are still considered as potential threats. Similarly, the COVID-19 which resulted in a pandemic situation has badly affected a large number of population across the globe. As the rate of genomic mutation is faster in case of coronavirus, it has become difficult to develop effective synthetic drug-based treatment strategies (Irwin et al. 2016). One of the drawbacks of synthetic antiviral drugs is that they display adverse side effects which would affect the human well-being. On the contrary, plant-derived drugs can be considered as a suitable alternative since herbal treatments exhibit minimal side effects with maximal health benefits (Biswas et al. 2019). For several emerging viral diseases, plant-derived compounds exhibiting antiviral properties have been evaluated and found to be effective and most importantly have been propsed to be applied along with the pre-existing therapies so as to enhance the efficacy (Kapoor et al. 2017; Lillehoj et al. 2018). The antiviral properties of the plant-based compounds are governed by a variety of mechanisms. It has been reported that few phytochemicals have the potential to restrict the entry of viruses primarily by ensuring unavailability of specific sites for attachment of viruses to specific host cells as the phytochemicals can bind to the carbohydrate moiety of the target host cell (Idris et al. 2016). Also, few phytomolecules inhibit viral replication and propagation and thus prevents the infectious action of viruses (Kapoor et al. 2017).

Phytomolecules can be strategically employed against viral infection by targeting any possible viral replication check-points. For example, the phytochemical; epigallocatechin gallate (EGCG) specifically inactivates the viral as well as host enzymes (reverse transcriptase, protease, RNA polymerase) and ultimately restricts the viral growth (Lipson et al. 2017). Another way the flavonoids restrict the viral RNA synthesis is by preventing protein phosphorylation resulting in inhibition of several viruses such as herpes simplex virus, influenza virus and HIV (Kumar and Pandey 2013). Several phytochemicals including fiestin, baicalein and quercetagetin have the potential to inhibit the chikungunya virus essentially by restricting the viral replication events (Lani et al. 2016). Similarly luteolin also possess antiviral replication activity during the post entry process as this phytochemical cannot inhibit the viral replication 
Table 1 Potent phytomolecules against coronavirus

\begin{tabular}{|c|c|c|c|c|}
\hline S.I. No & Name of plants & Phytomolecules & Mechanism of Action & References \\
\hline 1 & Allium sativum & Allicin & Inhibit SARS-3CLpro activity & Shang et al. (2019) \\
\hline 2 & Amaranthus tricolor & Amaranthin & $\begin{array}{l}\text { Inhibit 3CLpro interacting } \\
\text { through Thr26, Glu166, } \\
\text { Cys145, His41, Thr24 } \\
\text { H-bonding }\end{array}$ & ul Qamar et al. (2020) \\
\hline 3 & Astragalus membranaceus & Flavonoids, lectin, isoflavones & Inhibit SARS-3CLpro activity & Jo et al. (2020) \\
\hline 4 & Capsicum annum & Quercetin, Luteolin-7-glucoside & $\begin{array}{l}\text { Inhibit the cellular entry of SARS } \\
\text { CoV }\end{array}$ & $\begin{array}{l}\text { Miean et al. (2001), Chen et al. } \\
\text { (2008) }\end{array}$ \\
\hline 5 & Citrus sinensis & Naringenin & $\begin{array}{l}\text { Potential Inhibitor of COVID-19 } \\
\text { Main Protease }\end{array}$ & $\begin{array}{l}\text { Salehi et al. (2019), Khaerunnisa } \\
\text { et al. (2020) }\end{array}$ \\
\hline 6 & Dioscorea rhizoma & Saponins & $\begin{array}{l}\text { Activates macrophages and } \\
\text { inflammatory responses }\end{array}$ & $\begin{array}{l}\text { Wen et al. (2011), Cheng et al. } \\
\text { (2016) }\end{array}$ \\
\hline 7 & Dryopteris crassirhizoma & Sutchuenoside A & $\begin{array}{l}\text { Play significant role in regulation } \\
\text { of inflammatory process }\end{array}$ & Cheng et al. (2016) \\
\hline 8 & Ephedra sinica & $\begin{array}{l}\text { (3R)-3-O- } \beta \text {-D-glucopyranosyl-3- } \\
\text { phenyl propanoic acid }\end{array}$ & $\begin{array}{l}\text { Inhibits viral replication and } \\
\text { 3CLpro }\end{array}$ & Zhang et al. (2020a, b) \\
\hline 9 & Flos lonicerae & Chlorogenic acid & Inhibits viral replication & $\begin{array}{l}\text { Chen et al. (2004), Zhang et al. } \\
(2020 \mathrm{a}, \mathrm{b})\end{array}$ \\
\hline 10 & Fraxinus sieboldiana & Calceolarioside B & $\begin{array}{l}\text { Inhibit 3CLpro interacting } \\
\text { through His41, Gly143, } \\
\text { Cys145, Glu166, Thr24, Thr25 } \\
\text { H-bonding }\end{array}$ & ul Qamar et al. (2020) \\
\hline 11 & Galla chinensis & $\begin{array}{l}\text { Luteolin and tetra-O-gallol- } \beta \text {-D } \\
\text { glucose gall, tannin }\end{array}$ & $\begin{array}{l}\text { Avidly binds with surface spike } \\
\text { protein of SARS-CoV }\end{array}$ & Yi et al. (2004) \\
\hline 12 & Glycyrhizzae uralensis & Glycyrrhizin & Inhibit 3CLpro & Chen et al. (2004) \\
\hline 13 & Glycyrrhiza radix & $\beta$-sistosterol, Liquiritin & $\begin{array}{l}\text { Inhibit viral adsorption and } \\
\text { penetration }\end{array}$ & Cinatl et al. (2003) \\
\hline 14 & Glycyrrhiza uralensis & $\begin{array}{l}\text { Flavonoids, glycyrrhetinic acid } \\
\text { and Licoleafol }\end{array}$ & Inhibit SARS-3CLpro activity & $\begin{array}{l}\text { Jo et al. (2020), } \\
\text { ul Qamar et al. (2020) }\end{array}$ \\
\hline 15 & Houttuynia cordata & $\begin{array}{l}\text { Flavonoids, polysaccharides and } \\
\text { Quercitin }\end{array}$ & $\begin{array}{l}\text { Inhibit the viral SARS-3CLpro } \\
\text { activity and Block viral RNAde- } \\
\text { pendent RNA polymerase activ- } \\
\text { ity (RdRp) Immunomodulation }\end{array}$ & Lin et al. (2005), Lau et al. (2008) \\
\hline 16 & Hyptis atrorubens & Methyl rosmarinate & $\begin{array}{l}\text { Inhibit 3CLpro interacting } \\
\text { through Cys145, His41, Thr24, } \\
\text { Thr25, Thr26, H-bonding }\end{array}$ & ul Qamar et al. (2020) \\
\hline 17 & Isatis indigotica & $\begin{array}{l}\text { 5-hydroxyoxyindole, isaindigo- } \\
\text { tone, indole-3-carboxaldehyde }\end{array}$ & $\begin{array}{l}\text { Inhibit the cleavage activity of } \\
\text { SARS-3CLpro enzyme }\end{array}$ & Lin et al. (2005) \\
\hline 18 & Lonicera japonica & Iridoids & $\begin{array}{l}\text { Inhibits corona virus replication } \\
\text { at non-toxic concentration }\end{array}$ & Xiong et al. (2013) \\
\hline 19 & Lycium chinense & $\begin{array}{l}\text { Polyphenols, flavonoids, carot- } \\
\text { enoids }\end{array}$ & $\begin{array}{l}\text { Inhibit the viral SAES-3CL pro } \\
\text { activity }\end{array}$ & Miean et al. (2001) \\
\hline 20 & Lycoris radiata & Lycorine & Posses anticorona virus & Chen et al. (2004) \\
\hline 21 & Myrica cerifera & Myricitrin & $\begin{array}{l}\text { Inhibit 3CLpro interacting } \\
\text { through Gly143, Cys145, } \\
\text { His41, Thr24, Thr25, Thr26 } \\
\text { H-bonding }\end{array}$ & ul Qamar et al. (2020) \\
\hline 22 & Nigella sativa & $\begin{array}{l}\text { Thymoquinones, sterols and } \\
\text { saponins }\end{array}$ & $\begin{array}{l}\text { Increased production of inter- } \\
\text { ferons }\end{array}$ & Yimer et al. (2019) \\
\hline 23 & Olea europaea & Oleuropein & Exhibits high antioxidant activity & Nicolì et al. (2019) \\
\hline 24 & Phaseolus vulgaris & $\begin{array}{l}3,5,7,3^{\prime}, 4^{\prime}, 5^{\prime} \text { hexahydroxy } \\
\text { flavanone-3-Obeta-Dglucopyra- } \\
\text { noside }\end{array}$ & $\begin{array}{l}\text { Inhibit 3CLpro interacting } \\
\text { through His41, Cys145, } \\
\text { Thr24, Thr25, Thr26, Gln189 } \\
\text { H-bonding }\end{array}$ & ul Qamar et al. (2020) \\
\hline
\end{tabular}


Table 1 (continued)

\begin{tabular}{|c|c|c|c|c|}
\hline S.I. No & Name of plants & Phytomolecules & Mechanism of Action & References \\
\hline 25 & Phragmitis australis & lectins & $\begin{array}{l}\text { Inhibits corona virus by interfer- } \\
\text { ing with two targets in the viral } \\
\text { replication cycle }\end{array}$ & Keyaerts et al. (2007) \\
\hline 26 & Phyllanthus emblica & $\begin{array}{l}\text { (2S)Eriodictyol 7O-(6"'- } \\
\text { Ogalloyl)-beta D glucopyra- } \\
\text { noside }\end{array}$ & $\begin{array}{l}\text { Inhibit 3CLpro interacting } \\
\text { through Thr24, Thr25, Gly143, } \\
\text { Met49, Cys145, His41, Thr26 } \\
\text { H-bonding }\end{array}$ & ul Qamar et al. (2020) \\
\hline 27 & Psorothamnus arborescens & $\begin{array}{l}5,7,3^{\prime}, 4^{\prime} \text { 'Tetrahydroxy2'- } \\
\quad(3,3 \text { dimethylallyl) isoflavones }\end{array}$ & $\begin{array}{l}\text { Inhibit 3CLpro interacting } \\
\text { through His41, Cys 145, Thr24, } \\
\text { Thr25, Thr26, H-bonding }\end{array}$ & ul Qamar et al. (2020) \\
\hline 28 & Rheum palmatum & Emodin, Rhein & $\begin{array}{l}\text { Inhibit interaction of SARS-CoV } \\
\text { spike protein }\end{array}$ & $\begin{array}{l}\text { Ho et al. (2007), Cheng et al. } \\
\text { (2016) }\end{array}$ \\
\hline 29 & Saposhnikovia radix & Cimifugin & $\begin{array}{l}\text { Inhibitory effect against corona } \\
\text { virus }\end{array}$ & Zheng et al. (2011) \\
\hline 30 & Scutellaria baicalensis & Kaempferol & $\begin{array}{l}\text { Prevent the early stage of } \mathrm{HCoV} \text { - } \\
\text { 22E9 infection, including viral } \\
\text { attachment and penetration }\end{array}$ & Deng et al. (2012) \\
\hline 31 & Scutellariae radix & Baicalin & Antiviral activity & Islam et al. (2012) \\
\hline 32 & Spinacia oleracea & Kaempferol & $\begin{array}{l}\text { Prevent the early stage of infec- } \\
\text { tion, including viral attachment } \\
\text { and penetration }\end{array}$ & Dabeek et al. (2019) \\
\hline 33 & Tonna sinensis & Gallic acid, Quercetin & $\begin{array}{l}\text { Inhibit the cellular entry of } \\
\text { SARSCoV }\end{array}$ & Chen et al. (2008) \\
\hline 34 & Veronica linariifolia & Iridoid & $\begin{array}{l}\text { Binds with surface spike protein } \\
\text { of corona virus }\end{array}$ & Yi et al. (2004) \\
\hline
\end{tabular}

during the entry of virus into the host cell (Fan et al. 2016). It is also evident from recent studies that the pinocembrin specifically inhibits Zika virus replication during late early stages (Lee et al. 2019). Also, genistein effectively inhibits the post-replication events mediated by the entry of herpes $B$ virus (Lee et al. 2019). Interstingly, combinatorial effect of genistein and synthetic drugs such as ganciclovir and acyclovir has been found to be more effective (LeCher et al. 2019). Similarly, around 43 alkaloids have been reported which are effective against influenza virus. Majorly, the alkaloids are believed to induce interferons and macrophages which enhances the immunogenic response against the virus (Moradi et al. 2018). Likewise, alkaloids also play an important role in diminishing the effect of influenza virus by inhibiting the viral replication or by preventing the synthesis of viral proteins (Moradi et al. 2018). Commelina communis contains homonojirimycin (HNJ), an alkaloid which strongly inhibits the infectious activity of influenza virus (Zhang et al. 2013). Alkaloid such as loliolide extracted from Phyllanthus urinaria impairs the entry of Hepatitis C virus (HCV) into the host cell (Chung et al. 2016). Also plant extract from Aglaia sp. possess antiviral activity owing to the presence of terpenes which can act against HIV-1 primarily by restricting the viral proliferation because of phytochemical-generated cytotoxic environment. In similar fashion, the transition phase between S and G2/M of the cell cycle is inhibited by the 3, 4-secodammarane triterpenoid, which ultimately prohibits the viral dissemination (Esimone et al. 2010). Marrubium vulgare contains terpenes which are effective against HSV-1 (Fayyad et al. 2014). Honokiol, one of the lignin extracted from Magnolia tree are mostly used in Chinese medications (Fang et al. 2015). Honokiol is effective against dengue virus as it can stall the synthesis of dsRNA and replication event. Similarly, 3-hydroxy caruilignan C (3-HCL-C), a lignin prevents the viral transcriptional and translational phases (Wu et al. 2012). One of the Coumarin (C4) is known to supress the IHNV infection, essentially by promoting cellular damage and preventing apoptosis and thus can be one of the potential alternative measures for generating anti-IHNV drug/vaccine (Hu et al. 2019). A detailed study on the underlying molecular mechanism(s) which mediates silencing of viral activities inside the host cell is yet to be fully revealed.

\section{Conclusion and future prospective}

Traditional plants have been widely explored for the treatment of various illness including viral infections. The major advantage of phytochemicals is that they exhibit minimal toxicity and side effects. Now-a-days researchers are keen to reveal more plant-based molecules having tremendous 
potential against various diseases. Thousands of plantderived secondary metabolites have been used as antiviral, antioxidant and antibacterial chemicals as revealed in several in silico and in vitro studies. Interestingly, phytochemicals along with other synthetic compounds including drugs can also be treated as an effective approach against viral infections. But, at the same time detailed molecular mechanism including the dosage potency of phytochemicals also need to be elucidated. Since most of the prevailing therapies against viral infections are synthetic drug-based which display adverse side effects, it is most important to approach for developing strategies which would be cost effective and less harmful for the human beings. In this context, phytochemicals can be considered as a suitable alternative.

The year 2020 and till now it has been a disastrous year for the world population due to sudden outbreak of
Covid-19. Though the vaccines are given to the patients, but the recovery and disease infection rate is still at the peak, so the new drugs or vaccines with high efficiency is yet to be discovered. WHO strongly advocates in maintaining several preventive measures such as washing hands frequently, maintaining social distance, by avoiding crowded places and wearing mask frequently. Different lockdown plans are made by the government authorities to protect the public from this pandemic. Plant-derived bioactive molecules may play a significant role in developing traditional medications which would be a boon for the entire mankind. Many plants contain the natural derivative compounds having the antiviral properties, consequently effective drugs can be formulated and would be a stepping stone for combating against new strains of virus (Fig. 7). Phytomolecules have tremendous potential to act as anti-viral or anti-pathogen agents. Now-a-days,

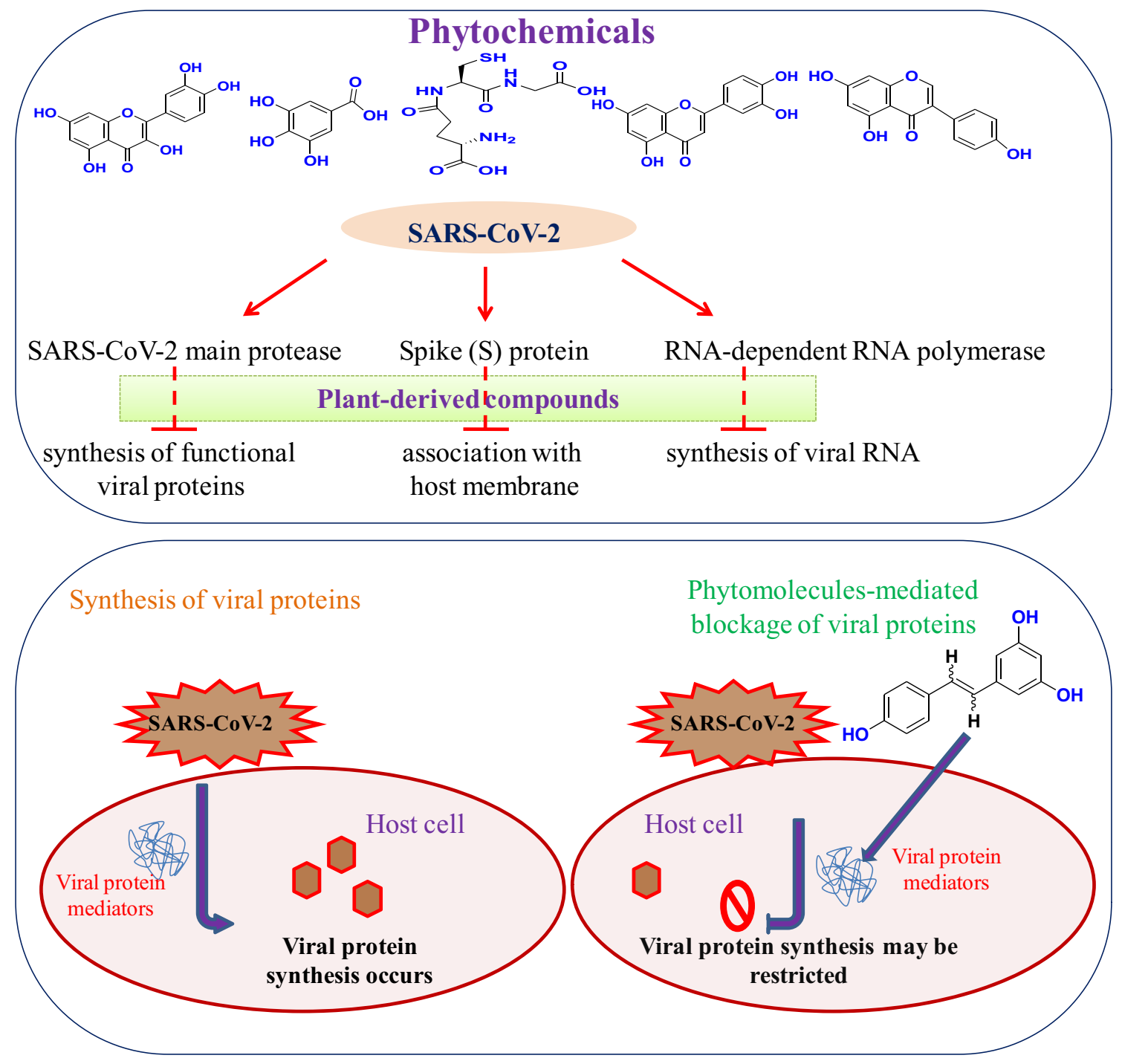

Fig. 7 Strategy to restrict the synthesis of SARS-CoV-2 proteins inside the host cell. Plant-derived molecules can be effectively recruited in the host cell specifically to prevent viral proliferation 
the brutal spread of the coronavirus is a wham to the mankind. Combined application of phytomolecules and FDAapproved synthetic drugs can be proved to be highly effective and thus related studies could be beneficial for a long-term preventive measure against viral pathogens. Additionally, repurposing of known phytochemicals which are effective against virus can be practised. Furthermore, nanotechnological interventions such as encapsulation of antiviral phytochemicals in nanoparticles can enhance the stability and delivery within the host cells. In addition, exploring biodiversity rich regions can also be advantageous in isolating antiviral phytomolecules. It is absolutely important to explore the bioactive molecules-based therapeutic measures and get ourselves prepared for future encounter with virus.

Acknowledgements Authors thank the administration and management of Centurion University of Technology and Management, Odisha, India for their heartfelt support. We apologize to all colleagues whose work could not be discussed owing to space limitations.

Author contribution All the authors have substantial contribution for the preparation of the manuscript. KBS and GKP conceived the idea. Data curation and writing: GKP, SKS, AS, SB, SS, AM and KBS. Review and editing: KBS, GKP, SKS and AS. All the authors have read and approved the final manuscript before submission.

Funding The present study was supported by the Centurion University of Technology and Management, Odisha, India. The financial support was provided to Gagan Kumar Panigrahi (GKP) and Shraban Kumar Sahoo (SKS) (Reference: CSREM TRUST BHUBANESWAR:UTRP UNBH21195785007).

\section{Declarations}

Ethical statement This article does not contain any studies involving animals performed by any of the authors. This article does not contain any studies involving human participants performed by any of the authors.

Conflict of interest Gagan Kumar Panigrahi has no conflict of interest. Shraban Kumar Sahoo has no conflict of interest. Annapurna Sahoo has no conflict of interest. Shibasish Behera has no conflict of interest. Snigdha Rani Sahu has no conflict of interest. Archana Dash has no conflict of interest. Kunja Bihari Satapathy has no conflict of interest.

\section{References}

Adem S, Eyupoglu V, Sarfraz I, Rasul A, Ali M (2020) Identification of potent COVID-19 main protease (Mpro) inhibitors from natural polyphenols: an in silico strategy unveils a hope against CORONA. Preprint 2020030333. https://doi.org/10.20944/prepr ints202003.0333.v1

Arti MK, Bhatnagar K (2020) Modeling and predictions for Covid 19 Spread in India. Preprint https://doi.org/10.13140/RG.2.2. 11427.81444

Azmir J, Zaidul ISM, Rahman MM, Sharif KM, Mohamed A, Sahena F, Jahurul MHA, Ghafoor K, Norulaini NAN, Omar AKM
(2013) Techniques for extraction of bioactive compounds from plant materials: a review. J Food Eng 117(4):426-436

Banerjee A, Kulcsar K, Misra V, Frieman M, Mossman K (2019) Bats and Coronaviruses. Viruses 11(1):E41. https://doi.org/10.3390/ v11010041

Biswas D, Nandy S, Mukherjee A, Pandey DK, Dey A (2019) Moringa oleifera Lam and derived phytochemicals as promising antiviral agents: a review. S Afr J Bot. https://doi.org/10.1016/j.sajb.2019. 07.049

Booth CM, Matukas LM, Tomlinson GA, Rachlis AR, Rose DB, Dwosh HA (2003) Clinical features and short term outcomes of 144 patients with SARS in the greater Toronto area. J Am Med Assoc 289:2801-2809

Burki TK (2020) Coronavirus in China. Lancet Respir Med 8(3):238

Chan JFW, Yuan S, Kok KH et al (2020) A familial cluster of pneumonia associated with the 2019 novel coronavirus indicating person-to-person transmission: a study of a family cluster. Lancet 395:514-523

Chang FR, Yen CT, Ei-Shazly M, Lin WH, Yen MH, Lin KH, Wu YC (2012) Anti-human coronavirus (anti-HCoV) triterpenoids from the leaves of Euphorbia neriifolia. Nat Prod Commun $7(11)$

Chen F, Chan KH, Jiang Y, Kao RYT, Lu HT, Fan KW, Cheng VCC, Tsui WHW, Hung IFN, Lee TSW, Guan Y (2004) In vitro susceptibility of 10 clinical isolates of SARS coronavirus to selected antiviral compounds. J Clin Virol 31(1):69-75

Chen CJ, Michaelis M, Hsu HK, Tsai CC, Yang KD, Wu YC, Cinatl J Jr, Doerr HW (2008) Toona sinensis Roem tender leaf extract inhibits SARS coronavirus replication. J Ethnopharmacol 120(1):108-111

Chen N, Zhou M, Dong X, Qu J, Gong F, Han Y, Qiu Y, Wang J, Liu Y, Wei Y, Yu T (2020) Epidemiological and clinical characteristics of 99 cases of 2019 novel coronavirus pneumonia in Wuhan, China: a descriptive study. Lancet 395(10223):507-513

Cheng C, Giri SS, Jun WJ, Kim HJ et al (2016) Immunomodulatory effects of a bioactive compound isolated from Dryopteris crassirhizoma on the Grass Carp Ctenopharyngodon idella. J Immunol Res 3068913:1-12

Chung CY, Liu CH, Burnouf T, Wang GH, Chang SP, Jassey A, Tai CJ, Tai CJ, Huang CJ, Richardson CD, Yen MH (2016) Activity-based and fraction-guided analysis of Phyllanthus urinaria identifies loliolide as a potent inhibitor of hepatitis $\mathrm{C}$ virus entry. Antiviral Res 130:58-68

Cinatl J, Morgenstern B, Bauer G, Chandra P, Rabenau H, Doerr HW (2003) Glycyrrhizin, an active component of liquorice roots, and replication of SARS-associated coronavirus. Lancet 361(9374):2045-2046

Clark DRJEM, Baillie JK (2020) Clinical evidence does not support corticosteroid treatment for 2019-nCoV lungs injury. Lancet 6736(20):30317-30322

Cui J, Li F, Shi ZL (2019) Origin and evolution of pathogenic coronaviruses. Nat Rev Microbiol 17(3):181-192

Dabeek WM, Marra MV (2019) Dietary Quercetin and Kaempferol: bioavailability and potential cardiovascular-related bioactivity in humans. Nutrients 11(10):1-15

Dash S, Panda MK, Singh MC, Jit BP, Singh YD, Patra JK (2020) Bioactive molecules from alpinia genus: a comprehensive review. Curr Pharma Biotechnol 21:1

Deng YF, Aluko RE, Jin Q, Zhang Y, Yuan LJ (2012) Inhibitory activities of baicalin against renin and angiotensin-converting enzyme. Pharmaceut Biol 50(4):401-406

Dias DA, Urban S, Roessner U (2012) A historical overview of natural products in drug discovery. Metabolites 2(2):303-336

Esimone CO, Eck G, Nworu CS, Hoffmann D, Überla K, Proksch P (2010) Dammarenolic acid, a secodammarane triterpenoid from 
Aglaia sp. shows potent anti-retroviral activity in vitro. Phytomedicine 17(7):540-547

Fan W, Qian S, Qian P, Li X (2016) Antiviral activity of luteolin against Japanese encephalitis virus. Virus Res 220:112-116

Fang CY, Chen SJ, Wu HN, Ping YH, Lin CY, Shiuan D, Chen CL, Lee YR, Huang KJ (2015) Honokiol, a lignan biphenol derived from the magnolia tree, inhibits dengue virus type 2 infection. Viruses 7(9):4894-4910

Fayyad AG, Ibrahim N, Yaakob WA (2014) Phytochemical screening and antiviral activity of Marrubium vulgare. Malays J Microbiol 10(2):106-111

Fehr AR, Channappanavar R, Perlman S (2017) Middle East respiratory syndrome: emergence of a pathogenic human coronavirus. Annu Rev Med 68:387-399

Giovanetti M, Benvenuto D, Angeletti S, Ciccozzi M (2020) The first two cases of 2019-nCoV in Italy: Where they come from? J Med Virol. https://doi.org/10.1002/jmv.25699

Gong SJ, Su XJ, Wu HP, Li J, Qin YJ, Xu Q, Luo WS (2008) A study on anti-SARS-CoV 3CL protein of flavonoids from Litchi Chinensis. Chin Pharma Bull 24(5):699-700

Griffith JF, Antonio GE, Kumta SM, Hui DSC, Wong JKT, Joynt GM (2005) Osteonecrosis of hip and knee in patients with severe acute respiratory syndrome treatment with steroids. Radiol 235:168-175

Guan W-J, Ni Z-Y, Hu Y, Liang W-H, Ou C-Q, He J-X et al (2020) Clinical characteristics of coronavirus disease 2019 in China. N Engl J Med. https://doi.org/10.1056/NEJMoa2002032

Hampton T (2005) Bats may be SARS reservoir. JAMA 294(18):2291

Hirsch HH, Martino R, Ward KN, Boeckh M, Einsele H, Ljungman $P$ (2013) Guidelines for diagnosis and treatment of human respiratory syncytial virus parainfluenza virus, metapneumovirus, rhinovirus and coronavirus. Clin Infect Dis 56:258-266

Ho TY, Wu SL, Chen JC, Li CC, Hsiang CY (2007) Emodin blocks the SARS coronavirus spike protein and angiotensin-converting enzyme 2 interaction. Antiviral Res 74(2):92-101

Hu Y, Chen W, Shen Y, Zhu B, Wang GX (2019) Synthesis and antiviral activity of Coumarin derivatives against infectious hematopoietic necrosis virus. Bioorg Med Chem Lett 29(14):1749-1755

Huang C, Wang Y, Li X, Ren L, Zhao J, Hu Y et al (2020) Clinical features of patients infected with 2019 novel coronavirus in Wuhan, China. Lancet 395:497-506. https://doi.org/10.1016/ S0140-6736(20)30183-5

Idris F, Muharram SH, Diah S (2016) Glycosylation of dengue virus glycoproteins and their interactions with carbohydrate receptors: possible targets for antiviral therapy. Arch Virol 161(7):1751-1760

Irwin KK, Renzette N, Kowalik TF, Jensen JD (2016) Antiviral drug resistance as an adaptive process. Virus Evol 2(1):vew14

Islam MN, Chung HJ, Kim DH, Yoo HH (2012) A simple isocratic HPLC method for the simultaneous determination of bioactive components of Scutellariae radix extract. Nat Prod Res 26(21):1957-1962

Jiang S, Xia S, Ying T, Lu L (2020) A novel coronavirus (2019-nCoV) causing pneumonia-associated respiratory syndrome. Cell Mol Immunol. https://doi.org/10.1038/s41423-020-0372-4

Jin YH, Cai L, Cheng ZS, Cheng H, Deng T, Fan YP, Fang C, Huang D, Huang LQ, Huang Q, Han Y (2020) A rapid advice guideline for the diagnosis and treatment of 2019 novel coronavirus (2019-nCoV) infected pneumonia (standard version). Military Med Res 7(1):4

Jo S, Kim S, Shin DJ, Kim MS (2020) Inhibition of SARS-CoV 3CL protease by flavonoids. J Enzyme Inhib Med Chem 35(1):145-151

Kang YB, Mallikarjuna PR, Fabian DA, Gorajana A, Lim CL, Tan EL (2013) Bioactive molecules: current trends in discovery, synthesis, delivery and testing. IeJSME 7(Suppl 1):S32-S46
Kapoor R, Sharma B, Kanwar SS (2017) Antiviral phytochemicals: an overview. Biochem Physiol 6(2):7

Keyaerts E, Vijgen L, Pannecouque C, Van Damme E, Peumans W, Egberink H, Balzarini J, Van Ranst M (2007) Plant lectins are potent inhibitors of coronaviruses by interfering with two targets in the viral replication cycle. Antiviral Res 75(3):179-187

Khaerunnisa S, Kurniawan H, Awaluddin R, Suhartati S, Soetjipto S (2020) Potential inhibitor of COVID-19 main protease (M pro) from several medicinal plant compounds by molecular docking study. Preprint https://doi.org/10.20944/preprints202003.0226

Kumar S, Pandey AK (2013) Chemistry and biological activities of flavonoids: an overview. Sci World J 2013:162750

Lani R, Hassandarvish P, Shu MH, Phoon WH, Chu JJ, Higgs S, Vanlandingham D, Bakar SA, Zandi K (2016) Antiviral activity of selected flavonoids against Chikungunya virus. Antiviral Res 133:50-61

Lau KM, Lee KM, Koon CM, Cheung CSF, Lau CP, Ho HM, Lee MYH, Au SWN, Cheng CHK, Bik-San Lau C, Tsui SKW (2008) Immunomodulatory and anti-SARS activities of Houttuynia cordata. J Ethnopharmacol 118(1):79-85

LeCher JC, Diep N, Krug PW, Hilliard JK (2019) Genistein has antiviral activity against herpes $\mathrm{B}$ virus and acts synergistically with antiviral treatments to reduce effective dose. Viruses 11(6):499

Lee LJ, Loe MW, Lee RC, Chu JJ (2019) Antiviral activity of pinocembrin against Zika virus replication. Antiviral Res 167:13-24

Li G, Clercq E (2020) Therapeutic options for the 2019 novel coronavirus (2019-nCoV). Nat Rev Drug Discov. https://doi.org/10. 1038/d41573-020-00016-0

Li SY, Chen C, Zhang HQ, Guo HY, Wang H, Wang L, Zhang X, Hua SN, Yu J, Xiao PG, Li RS (2005a) Identification of natural compounds with antiviral activities against SARS-associated coronavirus. Antiviral Res 67(1):18-23

Li W, Shi Z, Yu M, Ren W, Smith C, Epstein JH et al (2005b) Bats are natural reservoirs of SARS-like coronaviruses. Science 310(5748):676-679

Li Q, Guan X, Wu P, et al (2020a) Early transmission dynamics in Wuhan, China, of Novel Coronavirus-Infected Pneumonia New England. J Med, 1-9

Li T, Wei C, Li W, Hongwei F, Shi J (2020b) Beijing union medical college hospital on "pneumonia of novel coronavirus infection" diagnosis and treatment proposal. Med J Peking Union Med Coll Hosp https://kns.cnki.net/kcms/detail/11.5882.r.20200130.1430. 002.html

Lillehoj H, Liu Y, Calsamiglia S, Fernandez-Miyakawa ME, Chi F, Cravens RL, Oh S, Gay CG (2018) Phytochemicals as antibiotic alternatives to promote growth and enhance host health. Vet Res 49(1):76

Lin CW, Tsai FJ, Tsai CH, Lai CC, Wan L, Ho TY, Hsieh CC, Chao PDL (2005) Anti-SARS coronavirus 3C-like protease effects of Isatis indigotica root and plant-derived phenolic compounds. Antiviral Res 68(1):36-42

Lipson SM, Karalis G, Karthikeyan L, Ozen FS, Gordon RE, Ponnala S, Bao J, Samarrai W, Wolfe E (2017) Mechanism of antirotavirus synergistic activity by epigallocatechin gallate and a proanthocyanidin-containing nutraceutical. Food Environ Virol 9(4):434-443

Liu W, Morse JS, Lalonde T, Xu S (2020) Learning from the Past: Possible urgent prevention and treatment options for severe acute respiratory infections caused by $2019-\mathrm{nCoV}$. Chem Bio Chem, $730-738$

Lu, H (2020) Drug treatment options for the 2019-new coronavirus (2019-nCoV). Biosci Trends, 10-12

Lu R, Zhao X, Li J et al (2020) Genomic characterisation and epidemiology of 2019 novel coronavirus: implications for virus origins and receptor binding. Lancet 395:565-574 
Lung JH, Yu-Shih Lin Yao-Hsu Yang et al (2020) The potential chemical structure of anti-SARS-CoV-2 RNA-dependent RNA polymerase. J Med Virol, 10-19

Miean KH, Mohamed S (2001) Flavonoid (myricetin, quercetin, kaempferol, luteolin, and apigenin) content of edible tropical plants. J Agric Food Chem 49(6):3106-3112

Minneci PC, Deans KJ, Eichacker PQ, Natanson C (2009) The effects of steroids during sepsis depend on dose and severity of illness: an updated meta-analysis. Clin Microbiol Infect 15(4):308-318. https://doi.org/10.1111/j.1469-0691.2009.02752.x

Moradi MT, Karimi A, Lorigooini Z (2018) Alkaloids as the natural anti-influenza virus agents: a systematic review. Toxin Rev 37(1):11-18

Nguyen TTH, Woo HJ, Kang HK, Kim YM, Kim DW, Ahn SA, Xia Y, Kim D (2012) Flavonoid-mediated inhibition of SARS coronavirus 3C-like protease expressed in Pichia pastoris. Biotech Lett 34(5):831-838

Nicolì F, Negro C, Vergine M, Aprile A, Nutricati E, Sabella E, Miceli A, Luvisi A, De Bellis L (2019) Evaluation of phytochemical and antioxidant properties of 15 Italian Olea europaea L. Culti Leaves Mol 24(10):1-10

Panda S, Sahoo S, Tripathy K, Singh YD, Sarma MK, Babu PJ, Singh MC (2020) Essential oils and their pharmacotherapeutics applications in human diseases. Adv Tradit Med, 1-15

Panigrahi GK, Satapathy KB (2020a) Sacrificed surveillance process favours plant defense: a review. Plant Archives 20(1):2551-2559

Panigrahi GK, Satapathy KB (2020b) Arabidopsis DCP5, a decapping complex protein interacts with Ubiquitin-5 in the processing bodies. Plant Archives 20(1):2243-2247

Panigrahi GK, Satapathy KB (2020c) Formation of Arabidopsis Poly(A)-Specific Ribonuclease associated processing bodies in response to pathogenic infection. Plant Archives 20(2):4907-4912

Panigrahi GK, Satapathy KB (2020d) Potent Phytomolecules against the RNA dependent RNA polymerase of the SARS-COV-2. Biosc Biotech Res Comm 13(12):127-130

Panigrahi GK, Satapathy KB (2021) Pseudomonas syringae pv. syringae Infection orchestrates the fate of the Arabidopsis $\mathrm{J}$ domain containing cochaperone and decapping protein factor 5. Physiol Mol Plant Pathol 101598:1-9

Panigrahi GK, Sahoo A, Satapathy KB (2021) Insights to plant immunity: defense signaling to epigenetics. Physiol Mol Plant Pathol 101568:1-7

Paraskevis D, Kostaki EG, Magiorkinis G, Panayiotakopoulos G, Sourvinos G, Tsiodras S (2020) Full-genome evolutionary analysis of the novel corona virus (2019-nCoV) rejects the hypothesis of emergence as a result of a recent recombination event. Infect Genet Evol 79:104212

Paules CI, Marston HD, Fauci AS (2020) Coronavirus infections more than just the common cold. JAMA. https://doi.org/10.1001/jama. 2020.0757

Sahoo AS, Satapathy KB (2020) In Silico molecular docking-based screening reveals phytomolecules against SARS-COV-2 main protease. Biosc Biotech Res Comm 13(12):131-134

Salehi B, Fokou PVT, Sharifi-Rad M, Zucca P, Pezzani R, Martins N, Sharifi-Rad J (2019) The therapeutic potential of naringenin: a review of clinical trials. Pharmaceuticals 12(1):11

Shang A, Cao SY, Xu XY, Gan RY, Tang GY, Corke H, Mavumengwana V, Li HB (2019) Bioactive compounds and biological functions of garlic (Allium sativum L.). Foods 8(7):246

Shen YC, Wang LT, Khalil AT, Chiang LC, Cheng PW (2005) Bioactive pyranoxanthones from the roots of Calophyllum blancoi. Chem Pharm Bull 53(2):244-247

Shereen MA, Khan S, Kazmi A, Bashir N, Siddique R (2020) COVID19 infection: origin, transmission, and characteristics of human coronaviruses. J Adv Res 24:91-98
Singh AK, Singh A, Shaikh A, Singh R, Misra A (2020a) Chloroquine and hydroxychloroquine in the treatment of covid-19 with or without diabetes: a systematic search and a narrative review with special reference to India and other developing countries. Diabet Metab Syndrome Clin Res Rev 14:241-246

Singh YD, Jena B, Ningthoujam R et al (2020b) Potential bioactive molecules from natural products to combat against coronavirus. Adv Tradit Med (ADTM). https://doi.org/10.1007/ s13596-020-00496-w

Singh YD, Panda MK, Satapathy KB (2020c) Ethnomedicine for drug discovery. Advances in pharmaceutical biotechnology. Springer, Singapore, pp 15-28

Sun J, He WT, Wang L, Lai A, Ji X, Zhai X, Li G, Suchard MA, Tian J, Zhou J, Veit M (2020) COVID-19: epidemiology, evolution, and cross-disciplinary perspectives. Trends Mol Med 26(5):483-495

Ton A-T, Gentile F, Hsing M et al. (2020) Rapid Identification of Potential Inhibitors of SARS- CoV-2 Main Protease by Deep Docking of 1.3 Billion Compounds. Mol Inform, 1-18

ul Qamar MT, Alqahtani SM, Alamri MA, Chen LL (2020) Structural basis of SARS-CoV-2 3CLpro and anti-COVID-19 drug discovery from medicinal plants. J Pharmaceut Anal 10(4):313-319

Velavan TP, Meyer CG (2020) The COVID-19 epidemic. Trop Med Int Health. https://doi.org/10.1111/tmi.13383

Walter TM, Justinraj CS, Nandini VS (2020) Effect of Nilavembu kudineer in the Prevention and Management of COVID-19 by inhibiting ACE2 Receptor. Siddha Papers 15(2):1-9

Wang C, Horby PW, Hayden FG, Gao GF (2020a) A novel coronavirus outbreak of global health concern. Lancet 395:470-473

Wang M, Cao R, Zhang L, Yang X, Liu J, Xu M (2020b) Remdesivir and Chloroquine effectively inhibit the recently emerged coronavirus (2019-nCoV) in vitro. Cell Res 30:269-271

Wang Z, Chen X, Lu Y, Chen F, Zhang W (2020c) Clinical characteristics and therapeutic procedure for four cases with 2019 novel coronavirus pneumonia receiving combined Chinese and Western medicine treatment. Biosci Trends 14(1):64-68. https://doi. org/10.5582/bst.2020.01030

Wen CC, Kuo YH, Jan JT, Liang PH, Wang SY, Liu HG, Lee CK, Chang ST, Kuo CJ, Lee SS, Hou CC (2007) Specific plant terpenoids and lignoids possess potent antiviral activities against severe acute respiratory syndrome coronavirus. J Med Chem 50(17):4087-4095

Wen CC, Shyur LF, Jan JT, Liang PH, Kuo CJ, Arulselvan P, Wu JB, Kuo SC, Yang NS (2011) Traditional Chinese medicine herbal extracts of Cibotium barometz, Gentiana scabra, Dioscorea batatas, Cassia tora, and Taxillus chinensis inhibit SARS-CoV replication. J Tradit Complement Med 1(1):41-50

Woolley JG (2001) Plant alkaloids. De Montfort University Leicester, Nature Publishing Group, London, Encyclopedia of life sciences

Wrapp D, Wang N, Corbett KS et al (2020) Cryo-EM structure of the 2019-nCoV spike in the prefusion conformation. Science 1263:1260-1263

Wu SF, Lin CK, Chuang YS, Chang FR, Tseng CK, Wu YC, Lee JC (2012) Anti-hepatitis C svirus activity of 3-hydroxy caruilignan C from Swietenia macrophylla stems. J Viral Hepat 19(5):364-370

Wu F, Zhao S, Yu B et al (2020) A new coronavirus associated with human respiratory disease in China. Nature 579:265-269

Xiong J, Li S, Wang W, Hong Y, Tang K, Luo Q (2013) Screening and identification of the antibacterial bioactive compounds from Lonicera japonica leaves. Food Chem 138(1):327-333

Xu Z, Peng C, Shi Y, Zhu Z, Mu K, Wang X, Zhu W (2020) Nelfinavir was predicted to be a potential inhibitor of 2019-nCov main protease by an integrative approach combining homology modelling, molecular docking and binding free energy calculation. BioRxiv. https://doi.org/10.1101/2020.01.27.921627 
Yang L, Wen KS, Ruan X, Zhao YX, Wei F, Wang Q (2018) Response of plant secondary metabolites to environmental factors. Molecules 23(4):762

Yang Y, Islam MS, Wang J, Li Y, Chen X (2020) Traditional Chinese medicine in the treatment of patients infected with 2019-new coronavirus (SARS-CoV-2): a review and perspective. Int J Biol Sci 16(10): 1708

Yi L, Li Z, Yuan K, Qu X, Chen J, Wang G, Zhang H, Luo H, Zhu L, Jiang P, Chen L (2004) Small molecules blocking the entry of severe acute respiratory syndrome coronavirus into host cells. J Virol 78(20):11334-11339

Yimer EM, Tuem KB, Karim A, Ur-Rehman N, Anwar F (2019) Nigella sativa L. (Black Cumin): a promising natural remedy for wide range of illnesses. Evid Based Complement Alternat Med 2019:1528635

Zhang G, Zhang B, Zhang X, Bing F (2013) Homonojirimycin, an alkaloid from dayflower inhibits the growth of influenza a virus in vitro. Acta Virol 57(1):85-86

Zhang DH, Wu KL, Zhang X, Deng SQ, Peng B (2020a) In silico screening of Chinese herbal medicines with the potential to directly inhibit 2019 novel coronavirus. J Integr Med 18(2):152-158
Zhang H, Kang Z, Gong H, Xu D, Wang J, Li Z, et al (2020b) The digestive system is a potential route of 2019-nCov infection: a bioinformatics analysis based on single-cell transcriptomes. bioRxiv https://doi.org/10.1101/2020.01.30.927806

Zheng J (2020) SARS-CoV-2: an emerging coronavirus that causes a global threat. Int J Biol Sci 16(10):1678-1685

Zheng ZG, Wang RS, Cheng HQ, Duan TT, He B, Tang D, Gu F, Zhu Q (2011) Isolated perfused lung extraction and HPLC-ESI-MSn analysis for predicting bioactive components of Saposhnikoviae Radix. J Pharm Biomed Anal 54(3):614-618

Zhou P, Yang XL, Wang XG, Hu B, Zhang L, Zhang W, Si HR, Zhu Y, Li B, Huang CL, Chen HD (2020) A pneumonia outbreak associated with a new coronavirus of probable bat origin. Nature 579(7798):270-273

Zhu N, Zhang D, Wang W, Li X, Yang B, Song J et al (2020) A novel coronavirus from patients with pneumonia in China, 2019. N Engl J Med. https://doi.org/10.1056/NEJMoa2001017

Publisher's Note Springer Nature remains neutral with regard to jurisdictional claims in published maps and institutional affiliations.

\section{Authors and Affiliations}

\section{Gagan Kumar Panigrahi ${ }^{1}$. Shraban Kumar Sahoo ${ }^{1}$. Annapurna Sahoo ${ }^{1}$. Shibasish Behera ${ }^{1}$. Snigdharani Sahu ${ }^{1}$. Archana Dash ${ }^{1} \cdot$ Kunja Bihari Satapathy ${ }^{1}$}

Kunja Bihari Satapathy

kunjabihari.satapathy@cutm.ac.in
1 School of Applied Sciences, Centurion University of Technology and Management, Khurda, Odisha, India 